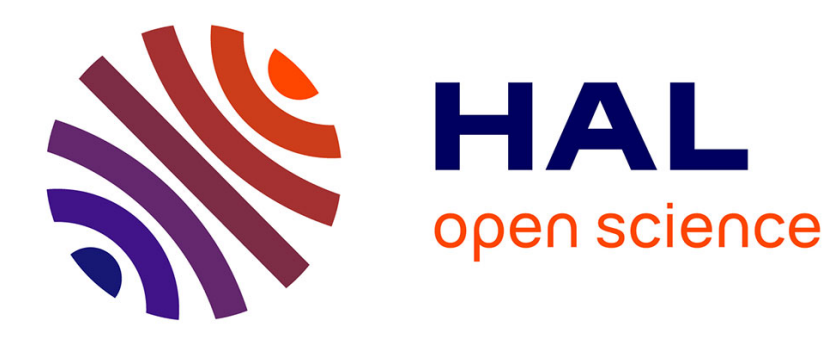

\title{
NEW WAYS OF WORKING: FROM SMART TO SHARED POWER
}

Laurent Taskin, Michel Ajzen, Céline Donis

\section{To cite this version:}

Laurent Taskin, Michel Ajzen, Céline Donis. NEW WAYS OF WORKING: FROM SMART TO SHARED POWER. Redefining Management, Springer, pp.65-79, 2017, 978-3-319-88732-6. halshs03511624

\section{HAL Id: halshs-03511624 \\ https://shs.hal.science/halshs-03511624}

Submitted on 5 Jan 2022

HAL is a multi-disciplinary open access archive for the deposit and dissemination of scientific research documents, whether they are published or not. The documents may come from teaching and research institutions in France or abroad, or from public or private research centers.
L'archive ouverte pluridisciplinaire $\mathbf{H A L}$, est destinée au dépôt et à la diffusion de documents scientifiques de niveau recherche, publiés ou non, émanant des établissements d'enseignement et de recherche français ou étrangers, des laboratoires publics ou privés. 


\title{
Running head: NEW WAYS OF WORKING: FROM SMART TO SHARED POWER
}

\section{New Ways of Working: From Smart to Shared Power}

\author{
Laurent Taskin
}

Ph.D., Professor of Human Resource and Organization Studies, Louvain School of Management, Université catholique de Louvain, Belgium. E-mail: laurent.taskin@uclouvain.be

\section{Michel Ajzen}

Teaching and research assistant, Ph.D. candidate in Human Resource Management at the School of Work and Employment Sciences, Université catholique de Louvain, Belgium.

Céline Donis

Ph.D., Senior researcher at laboRH Chair in Human management and labour transformations, Université catholique de Louvain, Belgium.

Varda Muhlbauer - Wes Harry Editors

\section{Redefining Management}

Smart Power Perspectives

Reference: Taskin, L., Ajzen, M., Donis, C. (2017) "New ways of working: From smart to shared power", In Muhlbauer, V. \& Harry, W. (Eds) Redefining Management: Towards the Use of Smart Power and the Liberation of Human Potential at work, 65-79. Springer. 


\title{
Running head: NEW WAYS OF WORKING: FROM SMART TO SHARED POWER
}

\begin{abstract}
This chapter questions the relevance of the concept of smart power in organization studies and, specifically, in the study of new ways of working (NWOW) implementation. NWOW embrace a broad set of organizational practices, ranging from spatial and temporal flexibility to selfmanagement. Beyond such set of (somehow traditional) work practices, the singularity of NWOW seems to lie in its governance epitome, valuing a peculiar philosophy of management, i.e. a more democratic way of managing organizations. The Smart power approach could play a key role in the effective implementation of NWOW. However, drawing on existing studies, we report some paradoxes making NWOW a piece of what may be seen as old-fashioned management practices and organizational pattern that, far from constituting a promise for alternative modes of governance, also constitute new attempts to disciplinarize employees. Claiming organizational rules need to be appropriated by actors in order to become effective, this chapter argues a smart power perspective is not relevant at the micro-level, where traditional approaches of power and agency are more complete. While considering innovative NWOW, smart power approach seems well relevant to analyze meso regulations and, especially, governance issues.
\end{abstract}

Key words: New ways of working, management, organization, governance, critical management studies. 


\section{Running head: NEW WAYS OF WORKING: FROM SMART TO SHARED POWER}

\section{Introduction}

While referring to a large -and somehow confused- number of practices and discourses, new ways of working are depicted today as an organizational mix of flexible work practices (focusing mainly on spatio-temporal flexibility), managerial modes (including self-management), organizational configurations of work (such as autonomous teams), and contributing to make workplace governance more democratic and transparent (Taskin, 2012). A number of factors driving the growth of New Ways of Working (NWOW) over recent decades have been identified, including the development of enabling technologies (Baruch and Nicholson, 1997), the increased economic importance of knowledge work (Kärreman and Alvesson, 2004), a greater awareness of sustainability and mobility issues (Perez, Sanchez, de Luis Carnicer and Vela Jimenez, 2004), the increased cost and space pressures (Felstead, Jewson and Walters, 2005; Neufeld and Fang, 2005), and the employees' desire to adopt them (Stanworth 1997; Baines and Gender 2003; Manoochehri and Pinkerton 2003).

NWOW concern many professional, technical, and clerical occupations in professional services industries of most developed countries and it is now commonly admitted that it involves a qualitative shift away from traditional forms of centralized social organization (bureaucracy) toward a more diffused, fragmented, and emergent set of social relations (see e.g. Kelliher and Richardson, 2012). To a large extent, the implementation of new ways of working is supported by a discourse on the need for a new "philosophy of management" promoting a more democratic governance, namely through the deployment of participatory and collaborative management (Taskin, 2012).

Far from this idyllic vision, critical research in management recently reports contrast evidence of such alternative forms of management and organizations, denouncing, for example, 


\section{Running head: NEW WAYS OF WORKING: FROM SMART TO SHARED POWER}

new ways of domination (Cheney, Santa Cruz Peredo and Nazareno, 2014; Parker, Cheney, Fournier and Land, 2014; Picard, 2015), and deskilling and work degradation effects (Taskin and Van Bunnen, 2015). Drawing on several research results, we report that, in many cases, new ways of working are imposed by management -instead of being co-developed with all the organization's members. So, in order to consider 'smart power' at the workplace, we decided to investigate how smart power could help to understand this specific tension in NWOW's governance in organizations.

The contribution of this chapter is twofold. First, it lightens the very notion of "new ways of working" through defining and characterizing the concept and its components. Second, it questions smart power at the workplace level as a possible condition of the effective production of new ways of working, pursuing an ideal of democratizing organization's governance.

\section{The Rise of NWOW: An Idealistic Philosophy of Management, But More of the Same?}

New ways of working are associated with a wide variety of work, organization and management practices and policies, ranging from home-based teleworking to quality management. In this section, we characterize and classify the organization and management practices claimed by new ways of working in the scientific and professional literatures -what leads us to identify practices that are not new. Then, we isolate what seems to be specific to such NWOW: the discourse that goes hand in hand with them and which advocates a specific vision of the company inspired from the Human Relations school of managing staff and work, i.e. where employees, management and employers are partners and trust each other and share a 


\section{Running head: NEW WAYS OF WORKING: FROM SMART TO SHARED POWER}

common concern about their well-being, promoting a more transparent and shared corporate governance.

\section{Context of emergence and development.}

For several decades, profound transformations of work have been observed in our societies, like inter alia globalization, digitalization, flexibilization and individualization. These changes have directly contributed to the emergence of new ways of working.

At a societal level, globalization is a fundamental trend (Huws, 2014) that makes organizational boundaries much more porous, but also refers to the financialization of the economy, i.e. the shift in gravity of economic activity from production to finance. But financialization also affects management in producing result management based on financial and performance indicators that are increasingly disconnected from 'real' work (lean management and high performance work systems develop in such context). Alongside this globalized context, the process of digitalization, i.e. the use of digital technologies and of data in order to improve performance by transforming business processes, also constitutes a major challenge for organizations. Information systems, including enterprise resource planning tools and data management emerged in this context. But such technological development also supported the spread of spatial and/or temporal flexibility practices (like home-based telework, coworking spaces, virtual teams) (see e.g. Vartiainen, 2006) allowing people to work anywhere, anytime.

Individualization is also characteristic of a major transformation of our Society. In the context of work, this has led to the individualization of the employment relationship (Devos and Taskin, 2005; Linhart, 2015) which took part of a shift of responsibility from organizations through management practices - to workers. Nowadays, being responsible is not only being 


\section{Running head: NEW WAYS OF WORKING: FROM SMART TO SHARED POWER}

responsible of both quality and quantity of work but also being responsible for ones' own career and employability. In this context, new ways of working developed as a strategy to be more flexible, adaptable and responsive to both market requirements and workers' individual demands for inter alia work-life balance or well-being (Geary, 2003; Knights, Thompson, Smith and Willmott, 1998). But, characterizing NWOW is not painless.

\section{Describing 'new' ways of working and finding 'old' work practices.}

This also-called "New World of Work" (in reference to Microsoft's aim to make organizations agile, productive and collaborative regardless of where workers are and what device they are using ${ }^{\mathrm{i}}$ ) refers to the common willingness to break with traditional ways of working which are associated to rigidity and no longer relevant to the realities of global competition (see e.g. Holman, Wall, Clegg, Sparrow and Howard, 2005; Warhurst and Thompson, 1998). Traditional, bureaucratic, top-down forms of organizing work have increasingly been criticized in favor of innovations like employee involvement, high performance work systems, quality circles, pay-for-knowledge, multi-skilling, or teamwork (Geary, 2003; Milkman, 1998).

Whereas a generic definition of NWOW remains debated, authors often agreed on four main components in order to characterize NWOW (Taskin, 2012). First, NWOW is related to the existence of flexible work arrangements and practices (mainly spatial and temporal flexible work practices, such as teleworking, shared offices or coworking -see e.g. Felstead, Jewson and Walters, 2005; Halford, 2005; Tietze and Musson, 2002). Second, it has been acknowledged that such a concept implies the development of participative management (Hennestad, 2000; Hislop, 2008; Laloux, 2014; Silva and Ben Ali, 2010). Third, the implementation of new organizational configurations of work appears as a prerequisite to manage people and work processes in regards 


\section{Running head: NEW WAYS OF WORKING: FROM SMART TO SHARED POWER}

to flexible practices (Barker, 1993; Bell and Kozlowski, 2002; Dixon and Panteli, 2010; Wenger, 1998). Finally, the fourth - inescapable - feature is the use of information and communication technologies (Bobillier Chaumon, 2003; Felstead et al., 2005; Huws, 2014; Richter, Meyer and Sommer, 2006). In summary, NWOW refers to (a) spatial and temporal flexible work practices; (b) specific organizational configurations of work; (c) participative and collaborative management practices, drawing on the extended use of ICTs. Table 1 draws on this characterization and presents a set of practices associated to the new ways of working in the scientific literature. Note that the flexible types of employment status (like zero-hour contract, temporary work or self-employed workers), neither neo-taylorist, de-humanized and other uberized forms of employment are part of NWOW.

Table 1. Review of practices associated to New Ways Of Working (Adapted from Ajzen, Donis and Taskin (2015))

Insert Table 1 about here

A quick look at Table 1 reveals that many of the practices reported there are far from being 'new' (see also van Meel, 2011). Management by objectives and other participative 


\section{Running head: NEW WAYS OF WORKING: FROM SMART TO SHARED POWER}

management practices have been studied from the early 1950's: one of the first experience of self-management took place in 1944 in the Brun biscuit manufacturing plant, in France. Similarly, open-plan offices were set up in the 1950s and home-based telework in the early 1970s (Haigh, 2012). So, what is 'new' with new ways of working, if any?

\section{Do 'New' Ways of Working Lie in a Specific Vision of Work and Organization They Intend to Serve and Promote?}

According to Taskin (2012), the 'novelty' lies in the fact that a synergistic mix of practices is supported by a discourse carrying a specific philosophy of management, i.e. which promotes a more democratic form of governance in organizations. Therefore, traditional work and management practices are not just superposed within organizations, but rather constitute configurations of NWOW. This involves a coherent grouping of practices, aligned to corporate strategy, and to both internal and external environment of the firm (e.g. institutional context, employment relations pattern, etc.). And, the coherence of this configuration should ultimately derive from the democratization purpose anchored in the philosophy of management that is pursued and announced.

"The new workplace can be defined as comprising an "historical new", i.e., the presence of new working practices, types of HR practices or bundles of practice, and an "experiential new", i.e., the presence of qualitatively different managerial and employee orientations and experiences of self and work" (Holman, Wood, Wall and Howard, 2005, p.5). 


\section{Running head: NEW WAYS OF WORKING: FROM SMART TO SHARED POWER}

In other words, NWOW not only refer to work and management practices within organizations, but propose a specific purpose of what should be organizations: a thoughtful place for the people working in.

Although the notion of "philosophy of management" remains strongly debated and partially unclear, Boncori and Mahieux (2012) mention that management policies choices are based on management models that are ideologically colored. The "philosophy of management" associated to discourses on new ways of working is humanist in nature: the employment relationship would be based on mutual trust, responsibility, autonomy and transparency, and attention would be granted to workers, their needs and their well-being (see e.g. Kelliher and Richardson, 2012; Peters, Poutsma, Van der Heijden, Bakker and de Bruijn, 2014).

In many respects, the designation 'NWOW' may seem abusive and ultimately constitute only new packaging with well-known organizational forms and widely known high-performance work systems (HPWS). This is particularly the case when NWOW is used as a label in order to flag modernity, even though the practices in question are put in place for the sole purpose of increasing productivity and economic and financial performances. This leads companies to claim NWOW while they just offer home-based teleworking one day a week to some of their employees, in a surveillance logic where teleworkers have to report their presence every 15 minutes by clicking on a popup. However, in other organizations, new ways of working are set up with the sincere aim of promoting a different vision of work and enterprise, i.e. a more democratic way of organizing. This (limited) democratization process is at the heart of the 'liberated enterprise' promoted by Carney and Getz (2009) which resembles a HPWS mould, and promotes various participatory and skill-enhancing schemes aiming at including workers in processes and activities that were formerly monopolized by management (Milkman, 1998). 


\section{Running head: NEW WAYS OF WORKING: FROM SMART TO SHARED POWER}

Autonomy, power-sharing and the consideration of stakeholders' expectations are thus central in this "philosophy of management".

In summary, new ways of working are more than a synergistic mix of work and management practices in organizations: it refers to particular values established in a "philosophy of management" suggesting, on the one hand, that corporate governance has to be more democratic and that management and work have to be more collaborative-minded, and, on the other hand, promoting a vision of an autonomous worker who would become more responsible and trustworthy. The emergence of NWOW is also a sign of the times. NWOW takes place in a particular context, that of collaborative economics (the so-called uberization of the economy and other platforms where individuals may express their needs and feel autonomous), among other major transformations (i.e. globalization, individualization or the recent rise of diverse communitarianism). Since NWOW do not only rely on work and management practices, but also involve a normative stance anchored in societal transformations, its implementation in organizations cannot be envisaged in a traditional top-down approach, which can be compared to a hard-power perspective in the organizational context. This would suggest NWOW are more compatible with soft power approaches.

\section{"Smart Power" at the Workplace}

The concept of "Smart Power" has been recently developed in the field of Political Sciences where it has been depicted as a combination of "Hard" and "Soft" power forms. The former refers to the capacity to coerce through tangible threats and payoffs such as the use of military actions or economic sanctions (Nye, 2004). The latter is more insidious and intangible. 


\section{Running head: NEW WAYS OF WORKING: FROM SMART TO SHARED POWER}

Soft power is "the ability to get what you want through attraction rather than coercion or payments.“..." When you can get others to want what you want, you do not have to spend as much on sticks and carrots to move them in your direction. Seduction is always more effective than coercion, and many values like democracy, human rights, and individual opportunities are deeply seductive. But attraction can turn to repulsion if we appear arrogant or hypocritical" (Nye, 2006, p. 26).

In other words, soft power refers to the ability to shape preferences of others through inducement, attraction or seduction. In the midst of such an approach, attraction interplays with values. The more the values are shared the more the use of soft power might be effective: "when our policies are seen as legitimate in the eyes of others, our soft power is enhanced" (Nye, 2006, p.26). In this vein, sources of soft power are always specific to the context.

In a nutshell, the main differences between hard and soft power strategies reside in the type of behaviors and resources developed to reach particular objectives. According to Nye (2004), hard power strategies refer to particular command behaviors such as coercion or inducement. Developing such behaviors involves specific resources such as force or sanctions for coercion, or payments and bribe for inducement. Soft power strategies involve particular behavior such as agenda setting or attraction. By removing the use of hard power, the aim is to co-opt more than to command. To do so, soft power strategies play on values and culture to attract and prefer to let institutions set the agenda (Nye, 2004).

Between these two approaches of power was developed the notion of "Smart Power", originally defined by the American Center for Strategic and International Studies. 


\section{Running head: NEW WAYS OF WORKING: FROM SMART TO SHARED POWER}

This refers to "neither hard nor soft—it is the skillful combination of both. Smart power means developing an integrated strategy, resource base, and tool kit to achieve American objectives, drawing on both hard and soft power. It is an approach that underscores the necessity of a strong military, but also invests heavily in alliances, partnerships, and institutions at all levels to expand American influence and establish the legitimacy of American action" (CSIS, 2007, p. 7).

In an interview for the Harvard Kennedy School, Joseph S. Nye - committed defender of "Smart power" approach for diplomatic purposes - explains how smart power is a mix of hard and soft power strategies through an example about the terrorist threat and the position of the United States.

"We had to use force, hard power, against the Taliban government. But when it comes to the broader question of winning over the hearts and minds of the main stream Muslims so that the hardliners cannot recruit them, the situation requires soft power (...) we need to recover the ability to combine our soft power with our hard power if we're going to build the capacity to use smart power”. (Nye, 2008 ${ }^{1}$ ).

Smart power then refers to a political approach that involves different means (tangible or intangible actions and coercion or co-opt strategies) to reach particular goals. In order to meet successfully such goals through a smart power strategy, Nye (2011) suggests to question first the

${ }^{1}$ This interview was leaded by Doug Gavel (Harvard University) on June 12, 2008. See Gavel, Doug. "Joseph Nye on Smart Power." Harvard Kennedy School Insight Interview, July 3, 2008. MOVE TO THE END PLEASE 


\section{Running head: NEW WAYS OF WORKING: FROM SMART TO SHARED POWER}

expected outcomes, the available resources and the particularities of the targeted audiences before planning what might be the most successful mix of hard and soft strategies.

At the workplace, this perspective echoes the political - or strategic - approach of actors proposed by Pfeffer (1981) and Michel Crozier (1964) in the 1960's and onwards. Actors are considered as possessing resources which they may use in order to influence other's behaviors (especially, their decisions). Power is considered as relational and it is admitted that some actors have more resources than others, but no one is powerless. In this perspective, actors are not States and the relations at stake do not take place in the context of diplomacy or international affairs. At the workplace, the actor commonly refers to groups of individuals sharing a same interest within an organization (operators, managers, blue collars, trade union, young workers, etc.) but this also have been transposed to an individual level.

So, at this stage, smart power invites to focus on the way NWOW are implemented in organizations by considering both management practices and discourses. In this perspective, a hard power approach would suggest NWOW are imposed on individuals who are compelled to work differently whereas a soft power perspective would refer to a situation where NWOW have been made desirable by management, for everyone. In between, a smart power perspective would balance these extremes and offer attractive possibilities to workers opting for NWOW, as well as constraining them who would not conform to them.

\section{Implementing NWOW: Towards an Instrumentalization of a Democratic Ideal}

NWOW encompass several configurations of managerial and organizational practices that have to be guided by a democratic ideal. But, how does it actually happen when NWOW are 


\section{Running head: NEW WAYS OF WORKING: FROM SMART TO SHARED POWER}

implemented in organizations? Is a smart power approach required to prevent NWOW simply becoming an additional policy of management only seeking to enhance the economic performance of the firm? What kind of management practices are set up to implement NWOW, and to what extent are these consistent with the discourse that supports NWOW implementation? In order to answer this question, we present research results that contribute to illustrate two main paradoxes in NWOW: (1) a discursive paradox, due to the risk of promoting a set of management practices that seek to increase productivity (also by reducing costs) in the name of a philosophy of management that promotes inter alia transparency; (2) a practice-based paradox, where NWOW are operated in a non-participative stance.

\section{NWOW as a mean to improve economic performance.}

Although NWOW is associated with a positive vision of human at work through participative practices and democratic governance, this is often not an end per se. In a metaanalysis of 162 case studies found in the literature (for details, see Ajzen et al., 2015), we identified four types of justifications to the development of NWOW: economic (productivity, efficiency, profit, etc.), organizational (flexibility, turnover, absenteeism, etc.); social (work-life balance, wellbeing, satisfaction, etc.) and environmental (traffic jam, pollution, etc.). Economic reasons were a constant to justify the implementation of NWOW practices. In some cases, organizational and social purposes were expressed whereas environmental ones never did. For the former ones, many cases reveal that if organizational or social factors are targeted as objectives, it is often considered as an intermediary step that will positively affect economical outcomes. This may be considered as a stupid functionalistic approach in management (Alvesson and Spicer, 2012) through which social and managerial innovations (like NWOW and its 


\section{Running head: NEW WAYS OF WORKING: FROM SMART TO SHARED POWER}

philosophy) are perverted and instrumentalized to maximize economic and financial performances.

As mentioned earlier, if NWOW practices are not so 'new', their association to the underlying management philosophy we mentioned earlier really is. Therefore, developing soft power strategies might be related to more transparency on the expected outcomes. Making NWOW desirable through the use of soft power strategies would involve to work on shared values by giving more opportunities to employees to engage in more democratic and participative governance systems.

As mentioned above, smart power is an approach that combines both hard and soft power strategies. In the case of NWOW, the soft power approach is more likely to refer to discourses aiming to enroll workers into new ways of working by different means such as attraction or seduction. However, as Nye (2006) mentions "attraction can turn to repulsion if [it] appear[s] arrogant or hypocritical" (p. 26). Workers are not dupes. Quite the opposite, as pointed by Cushen and Thompson (2012), workers are perfectly aware of internal tensions between expected outcomes and the underlying managerial rhetoric that aims to make NWOW desirable, for everyone. Many studies have shown how workers are able to resist strategies when such inconsistency appears (e.g. Bélanger and Thuderoz, 2010; Courpasson, Dany and Clegg, 2012).

Trying to further explore the combination of soft and hard power in the implementation of NWOW, and to statute on the smart power perspective in the context of NWOW, we propose to investigate the specific question of employees' participation. Our assumption is that the implementation of participative management practices should not be accompanied by forms of hard power. 


\section{Running head: NEW WAYS OF WORKING: FROM SMART TO SHARED POWER}

\section{NWOW as a managerial (but not too) participative project.}

In 2013, we conducted a survey among 481 Belgian companies with the intention to question the link between NWOW and the sustainable organizational performance. Among many results, this research provides some evidence regarding the level of workers' participation in the implementation of NWOW practices (Taskin and Ajzen, 2015). Each respondent had to choose among the four following options (not involved, involved through workers' representatives, involved by means of taskforces, involved by means of a questionnaire). Table 2 shows the percentage of each option for each NWOW practice. Multiple answers were allowed.

Table 2. Workers participation in implementing NWOW practices (Source: Taskin and Ajzen, 2015)

Insert Table 2 about here

Some NWOW-related practices have reached a high level of participation through working groups such as the participative management (74.5\% - Fortunately!) and (semi-) autonomous teams $(65.2 \%)$. By contrast, other practices were often implemented on a strictly top-down tradition. This was particularly the case for telework practices (60\%), open-space $(61.5 \%)$, virtual teams $(62.1 \%)$, and share-desks $(64.8 \%)$. One explanation might be that latter 


\section{Running head: NEW WAYS OF WORKING: FROM SMART TO SHARED POWER}

practices are more often implemented for performance purposes whereas (semi-) autonomous teams and participative management practices are more related to the organization of work. However, in cases where workers where involved through their representatives or by means of a questionnaire, we do not have information on to what extent answers were taken into consideration or how the involvement of workers representatives is limited to an information and consultation procedure or rather to a negotiation between social partners.

Notwithstanding, the poor level of workers' participation, in the implementation of some NWOW-related practices some results are particularly surprising. Whereas the philosophy of management underlying NWOW promotes a more democratic and participative approach, some NWOW-related practices seem to be mainly imposed by the management. In other words, the implementation of some NWOW-related practices is led by hard power strategies, by means of command and coercion. In this vein, NWOW's democratic ideal seems to be perverted and instrumentalized (Ajzen et al., 2015). However, power studies in the field of organization sciences show how actors will appropriate the rules in the production of specific uses, practices, collective strategies and routines (see e.g. Reynaud, 1979; Courpasson, 2000; Crozier \& Friedberg, 1977 or Taskin and Edwards, 2007, in the specific context of NWOW). To conclude this point, developing a hard power strategy to implement NWOW would be, on the one hand, inappropriate regarding power issues that take place in organizations and, on the other hand, inconsistent with the NWOW philosophy of management.

\section{Discussion}

These two illustrations show the impressive capability of management to functionalize a social innovation including, in the context of NWOW, its philosophy. The 'smart power' 


\section{Running head: NEW WAYS OF WORKING: FROM SMART TO SHARED POWER}

discussion we proposed in this chapter in fact shows some inconsistencies in the combination of hard and soft power perspectives in the specific context of NWOW implementation.

The illustrations above lead us to identify organizational (and managerial) paradoxes (Smith and Lewis, 2011) in the implementation of NWOW, and in the 'smart power' perspective we adopted. A first paradox refers to the participatory character of NWOW. While trust, democratization, transparency are at the heart of the NWOW's philosophy of management, we reported that a large number of organizations implementing NWOW did it in an autocratic way. A second paradox draws on more qualitative research and illustrates the inconsistency that was observed between NWOW's philosophy of management, perfectly transposed in managerial discourses on empowerment, and the ultimate purpose associated to them (in many case: being more productive, saving costs).

The smart power approach, as developed in the political sciences field, suggests considering a mix of hard and soft power strategies (Nye, 2011). Nevertheless, we show that juxtaposition of hard and soft power strategies would be inappropriate in the case of NWOW. This is consistent with Nye's work (2011) which describes smart power as a comprehensive approach more than a sum of strategies. Hence, a smart power strategy would require a more integrated strategy based on more transparency about the goals an organization pursues when implementing NWOW. As said earlier, workers might be aware of the purposes and the consequences of their implementation; they also might take part in this process in order to develop organizational shared values and express their views if these practices are not appropriate for their particular work context. In this regard, the smart power approach adopted here reminds us that HR and management policies are the result of a social process "involving choice and often negotiation between management and labour" (Edwards and Wajcman, 2005, p. 


\section{Running head: NEW WAYS OF WORKING: FROM SMART TO SHARED POWER}

25). One cannot impose on employees a willingness to cooperate, to trust each other and/or to take part to the decision-process. In order to illustrate what Edwards and Wajcman (2005) call "negotiation", we refer to Burawoy (1979) who claimed that negotiation among workers is inevitable when the rules of the game are externally imposed. Moreover, far from the 'power' issue we discussed in this chapter, recent studies report that NWOW may shape organisational and professional identities.

\section{Conclusion}

New ways of working are made of a large variety of seemingly traditional management and organizational practices such as teamwork, telework or self-management, as well as of a specific philosophy of management that promotes trust, responsibility, autonomy and a more democratic corporate governance. This chapter has shown how the 'new' character of NWOW, i.e. its philosophy of management, was set aside, to the benefit of traditional management and work practices. Paradoxically, a managerial innovation that should promote a shared governance of the firm has the consequence of achieving the opposite effect. As several critical research have shown, NWOW practices (as listed in Table 1) may lead to increase disciplinarization, surveillance, deskilling and work degradation (see e.g. Proenca, 2010; Stohl \& Cheney, 2001; Taskin \& Raone, 2014; Taskin \& Van Bunnen, 2015), far from the purpose of promoting responsibility, transparency, well-being or trust.

In line with this field of research, this chapter has brought several examples of how NWOW are perverted and instrumentalized to maximize economic and financial performances. This calls for further consideration. For example, to what extent the performance concern is 


\section{Running head: NEW WAYS OF WORKING: FROM SMART TO SHARED POWER}

really compatible with such philosophy of management that promotes empowerment, autonomy and emancipation? This question does not require removing the performance debate from the NWOW discussion but rather to consider other performances issues apart from the economic and financial ones by re-introducing elements such as well-being, work-life balance, autonomy, humanization at work, the feeling to be empowered or the "in-role" performance. By saying that, it becomes clear that implementing NWOW cannot be reduced to a speculative calculation. For instance, empowering the workforce or developing working conditions that promote a better balance between work and family does not follow the markets laws (see financialization discussed above). In this context, investing in work organization and workers may require reconsidering performance from a long-term perspective (Taskin and Ajzen, 2015).

Another issue this chapter raises is that implementing NWOW is not just about practices but it is also related to the ways practices are implemented. According to the research results presented here, many NWOW are implemented in more autocratic ways. It is as if participative management tools were imposed to workers or as if autonomous teams were developed with a low level of discretionary power. Quite the opposite, NWOW suggests renewing the traditional approach to corporate governance (owners delegate the management to (top) management, which is responsible for meeting performance targets that have been assigned -this is a purely top-down relationship). Fundamentally, by promoting trust and workers' participation in decision-making, NWOW invites a re-visit to the traditional governance of firms through, ultimately, sharing it. But the research we conducted and reviewed in this chapter did not focus on the ability of such organizational innovation to modify the traditional corporate governance norms; their focus was on the way NWOW were implemented in organizations. So, the description of this managerial 


\section{Running head: NEW WAYS OF WORKING: FROM SMART TO SHARED POWER}

project in a soft or hard power perspective strongly depends on the organizational context (including power distribution, organizational control modes and the division of labour), and does not allow assessment of the effectiveness of NWOW (for example -while high teleworking adoption rates may suggest the success of telework, it may be imposed and create much of tensions, far from attesting of a transparent, co-managed firm).

To conclude, we do not think the soft or hard power perspectives can explain much of this conundrum. We do think the object of this power relation is misplaced, from a smart power perspective. We suggest research investigating smart power issues at the workplace should consider macro and meso phenomena (like governance) instead of focusing on organizational projects (at a micro level). Indeed, political sciences have shown their ability to study the regulation processes at meso and macro levels, namely drawing on neo-institutionalism. Among the possible research avenues we would like to mention are the perspective of investigating the transformations of corporate governance of public, not-for-profit or for-profit organizations through the lenses of soft-smart-hard power seems especially promising. This suggests we consider corporate governance as being subject to multiple institutional influences, while also being co-produced by organization members.

\section{References}




\section{Running head: NEW WAYS OF WORKING: FROM SMART TO SHARED POWER}

Ajzen, M., Donis, C., \& Taskin, L. (2015). Kaléidoscope des Nouvelles Formes d'Organisation du Travail : L'instrumentalisation stupide d'un ideal collaborative et démocratique. Gestion $2000,31(3), 125-148$.

Alvesson, M., \& Spicer, A. (2012). A stupidity-based theory of organizations. Journal of Management Studies, 49(7), 1149-1220.

Baines, S., \& Gender, U. (2003). What is family friendly about the workplace in the home? The case of self-employed parents and their children. New Technology, Work and Employment, $18(3), 223-234$

Barker, J. (1993). Tightening the Iron Cage : Concertive Control in Self-Managing Teams. Administrative Science Quarterly, 38(3), 408-437.

Baruch, Y., \& Nicholson, N. (1997). Home, sweet home: requirements for effective home working. Journal of General Management, 23(2), 15-30.

Bélanger, J., \& Thuderoz, C. (2010). Le répertoire de l'opposition au travail. Revue Française de Sociologie, 51(3), 427-460.

Bell, B., \& Kozlowski, S. (2002). A typology of virtual teams : Implications for effective leadership. Group \& Organization Management, 27(1), 14-49.

Bobillier Chaumon, M.E. (2003). Evolutions techniques et mutations du travail : émergence de nouveaux modèles d'activité. Le Travail Humain, 66 (2), 161-192

Boncori, A-L., \& Mahieux, X. (2012). Au-delà du bien et du mal. La théorie et les pratiques de gestion. Revue Française de Gestion, n²28-229, 129-146

Burawoy, M. (1979). Manufacturing consent. Chicago: University of Chicago Press. 


\section{Running head: NEW WAYS OF WORKING: FROM SMART TO SHARED POWER}

Carney, B., \& Getz, I. (2009). Freedom, Inc. : Free your employees and let them lead your business to higher productivity, profits, and growth, New York : Random House Inc.

CSIS. (2007). Center for Strategic and International Studies commission on smart power. A smarter, more secure America (pp. 82): CSIS.

Cheney, G, Santa Cruz, Peredo, A-M., \& Nazareno, E, (2014). Worker cooperatives as an organizational alternative: Challenges, achievements and promise in business governance and ownership. Organization, 21(5), 591-603.

Courpasson, D., Dany, F., \& Clegg, S. (2012). Resisters at Work: Generating Productive Resistance in the Workplace. Organization Science, 3(May-June), 801-819.

Courpasson, D. (2000). L'action contrainte. Paris : Presses Universitaires de France.

Crozier, M. \& Friedberg, E. (1977). L'acteur et le système. Paris : Seuil.

Crozier, M. (1964). Pouvoir et organisation. European Journal of Sociology, 5(1), 52-64.

Cushen, J., \& Thompson, P. (2012). Doing the right thing? HRM and the angry knowledge worker. New Technology, Work and Employment, 27(2), 79-92.

Devos, V., \& Taskin, L. (2005). Entre individualisation et autonomie contrôlée. Gestion par les compétences et nouvelles formes d'organisation du temps et de l'espace. Revue Française de Gestion, 31(156), 93-104.

Dixon, K., \& Panteli, N. (2010). From virtual teams to virtuality in teams. Human Relations, 63(8), 1177-1197.

Edwards, P. \& Wajcman, J. (2005). The politics of working life. Oxford: Oxford University Press. 


\section{Running head: NEW WAYS OF WORKING: FROM SMART TO SHARED POWER}

Felstead, A., Jewson, N., \& Walters, S. (2005). Changing Places of Work. London : Palgrave.

Gavel, D. (2008). Joseph Nye on Smart Power. Harvard Kennedy School Insight Interview, (http://belfercenter.ksg.harvard.edu/publication/18419/joseph_nye_on_smart_power.html).

Geary, J. (2003). New forms of work organization : still limited, still controlled, but still welcome ? In Edwards, P. (Ed.). Industrial Relations, Theory and Practice. Oxford: Blackwell Publishing, Ltd, 338-367.

Haigh (2012). The Office. Melbourne : The Miegunyah Press.

Halford, S. (2005). Hybrid workspace: re-spatialisations of work, organisation and management. New Technology, Work and Employment, 20(1), 19-33.

Hennestad, B. (2000). Implementing Participative Management. Transition Issues from the field. The journal of Applied Behavioral Science, 36(3), 314-335.

Hislop, D. (2008). Mobility and Technology in the Workplace. New-York: Routeldge.

Holman, D., Wall, T., Clegg, C., Sparrow, P., \& Howard, A. (2005). The Essentials of the New Workplace. A guide to the human impact of modern working practices. Chichester : John Wiley \& Sons, Ltd.

Holman, D., Wood, S., Wall, T., \& Howard, A. (2005). Introduction to the Essentials of the New Workplace. In Holman, D., Wall, T., Clegg, C., Sparrow, P., \& Howard, A. (Eds.). The Essentials of the New Workplace. A guide to the human impact of modern working practices. Chichester : John Wiley \& Sons, Ltd., 1-14.

Huws, U. (2014). Labor in the global digital economy: the cybertariat comes of age. New-York: Monthly Review Press. 


\section{Running head: NEW WAYS OF WORKING: FROM SMART TO SHARED POWER}

Kärreman, D., \& Alvesson, M. (2004). Cages in tandem : Management control, social isolation, and identification in a knowledge-intensive firm, Organization, 11(1), 149-175

Kelliher, C., \& Richardson, J. (2012). New ways of organizing work. London: Routledge

Knights, D., Thompson, P., Smith, C., \& Willmott, H. (Eds.). Workplaces of the Future. New York : Palgrave.

Laloux, F. (2014). Reinventing organizations : A guide to creating organizations inspired by the next stages of human consciousness. Bruxelles : Nelson Parker

Linhart, D. (2015). La comédie humaine du travail - De la déshumanisation taylorienne à la surhumanisation managériale. Toulouse : Erès

Manoochehri, G., \& Pinkerton, T. (2003). Managing telecommuters: Opportunities and challenges. American Business Review, 21(1), 9-16.

Milkman, R. (1998). The New American Workplace : High Road or Low Road ? In Knights, D., Thompson, P., Smith, C., \& Willmott, H. (Eds.). Workplaces of the Future. New York : Palgrave, 25-39.

Neufeld, D., \& Fang, Y. (2005). Individual, social and situational determinants of telecommuter productivity. Information \& Management, 42(7), 1037-1049.

Nye, J.S (2004). Soft power. The means to success in world politics. Public Affairs: Cambridge

Nye, J.S. (2006). Soft Power and European-American Affairs. In T. L. Ilgen (Ed.), Hard Power, Soft Power and the future of Translatlantic Relations. CornWall: Ashgate, 25-38

Nye, J.S. (2011). The Future of Power. New York: Public Affairs. 


\section{Running head: NEW WAYS OF WORKING: FROM SMART TO SHARED POWER}

Parker M., Cheney G., Fournier V., \& Land, C. (Eds.) (2014). The Routledge Companion to Alternative Organization, London: Routledge.

Perez, M., Sanchez, A., de Luis Carnicer, M., \& Vela Jimenez, M. (2004). The environmental impacts of teleworking: A model of urban analysis and a case study. Management of Environmental Quality, 15(6), 656-671.

Peters, P., Poutsma, E., Van der Heijden, B., Bakker, A., \& de Bruijn, T. (2014). Enjoying new ways to work: an HRM- Process approach to study flow. Human Resource Management, 53(2), 271-290.

Pfeffer, J. (1981). Power in organizations. Marshifeld : Pitman.

Picard, H. (2015). “Entreprises libérées”, Parole libérée ? Lectures critiques de la participation comme projet managérial émancipateur, Université Paris-Dauphine : Paris.

Proenca, T. (2010). Self-managed work teams: An enabling or coercive nature. International Journal of Human Resource Management, 21(3), 337-354.

Reynaud, J.-D. (1979). Conflict and social regulation: A sketch of a theory of joint regulation. British Journal of Industrial Relations, 17(3), 314-321.

Richter, P., Meyer, J., \& Sommer, F. (2006). Well-being and stress in mobile and virtual work. In J. Andriessen \& M. Vartiainen (Eds.), Mobile virtual work. A new paradigm? Heidelberg: Springer, 231-252.

Silva, F., \& Ben Ali, A. (2010). Emergence du travail collaboratif: nouvelles formes d'organisation du travail. Management \& Avenir, 6(36), 340-365. 


\section{Running head: NEW WAYS OF WORKING: FROM SMART TO SHARED POWER}

Smith, W.K. \& Lewis, M.W (2011) 'Toward a theory of paradox: a dynamic equilibrium model of organizing'. Academy of Management Review, 36 (2), 381-403

Stanworth, C. (1997) 'Telework and the information age'. New Technology, Work and Employment, 13(1), 51-62.

Stohl, C., \& Cheney, G. (2001). Participatory Processes / Paradoxical Practices. Communication and the Dilemmas of Organizational Democracy. Management Communication Quartely, 14(3), 349-407.

Taskin, L., \& Edwards, P.K. (2007). The possibilities and limits of telework in a bureaucratic environment: Lessons from the public sector. New Technology, Work and Employment, 22(3), 195-207.

Taskin, L., \& Ajzen, M. (2015). Managing sustainable and innovative workplaces: NWOW, towards sustainable organizational performance? Louvain-la-Neuve: Louvain School of Management Research Institute - UCL.

Taskin, L., \& Van Bunnen, G. (2015). Knowledge management through the development of knowledge repositories: Towards work degradation, New Technology, Work and Employment, $30(2), 158-172$.

Taskin, L. \& Raone, J. (2014). Flexibilité et disciplinarisation : repenser le contrôle en situation de distanciation, Economies et Sociétés, Série «Etudes critiques en management », KC, 3 (1), 35-69.

Taskin, L. (2012). New ways of organizing work: Developments, perspectives and experiences, Management Learning, 43(4), 467-469 


\section{Running head: NEW WAYS OF WORKING: FROM SMART TO SHARED POWER}

Tietze, S., \& Musson, G. (2002). When work comes home: Coping strategies of teleworkers and their families. Journal of Business Ethics, 41(4), 385-396.

van Meel, J. (2011). The origins of new ways of working. Facilities, 29(9/10), 357-367.

Vartiainen, M. (2006). Mobile virtual work - Concepts, outcomes and challenges. In J. Andriessen \& M. Vartiainen (Eds.), Mobile virtual work. A new paradigm? (pp. 12-44). Heidelberg: Springer.

Warhurst, C., \& Thompson, P. (1998). Hands, Hearts and Minds : Changing Work and Workers at the End of the Century. In Knights, D., Thompson, P., Smith, C. \& Willmott, H. (Eds). Workplaces of the Future. New York : Palgrave, 1-24.

Wenger, E. (1998). Communities of practice: learning, meaning and identity, Cambridge : Cambridge University Press.

\section{Tables}

Table 1. Review of practices associated to New Ways Of Working

\begin{tabular}{|c|c|c|}
\hline $\begin{array}{c}\text { Spatial and -temporal flexible } \\
\text { work practices }\end{array}$ & $\begin{array}{c}\text { Organizational } \\
\text { configurations of work }\end{array}$ & $\begin{array}{c}\text { Participative and } \\
\text { collaborative } \\
\text { management }\end{array}$ \\
\hline Work from home & $\begin{array}{c}\text { Semi-autonomous and } \\
\text { autonomous teams }\end{array}$ & Knowledge Management \\
\hline Shared desks & Virtual teams & $\begin{array}{c}\text { Management by } \\
\text { objectives }\end{array}$ \\
\hline Clean desk policies & Open space & Project management \\
\hline Co-working & Network organizations & Collaborative autonomy \\
\hline Satellite offices & & Participative management \\
\cline { 3 - 3 } $\begin{array}{c}\text { Home-based telework (continuous, } \\
\text { alternated or occasional) }\end{array}$ & $\ldots$ & $\begin{array}{c}\text { Total Quality } \\
\text { Management }\end{array}$ \\
\hline
\end{tabular}


Running head: NEW WAYS OF WORKING: FROM SMART TO SHARED POWER

\begin{tabular}{|c|l|l|}
\hline Mobile telework & & Lean production \\
\hline
\end{tabular}

Adapted from Ajzen, Donis and Taskin (2015)

Table 2. Workers participation in implementing NWOW practices

\begin{tabular}{|l|c|c|c|c|}
\hline & Not involved & $\begin{array}{c}\text { Involved through } \\
\text { workers' } \\
\text { representatives }\end{array}$ & $\begin{array}{c}\text { Involved by } \\
\text { means of } \\
\text { taskforces }\end{array}$ & $\begin{array}{c}\text { Involved by } \\
\text { means of a } \\
\text { questionnaire }\end{array}$ \\
\hline $\begin{array}{l}\text { Management } \\
\text { by objectives }\end{array}$ & $41,3 \%$ & $8,3 \%$ & $46,5 \%$ & $11,1 \%$ \\
\hline $\begin{array}{l}\text { (Semi-) } \\
\text { autonomous } \\
\text { teams }\end{array}$ & $0,9 \%$ & $2,6 \%$ & $65,2 \%$ & $3,5 \%$ \\
\hline $\begin{array}{l}\text { Participative } \\
\text { management }\end{array}$ & $20,0 \%$ & $5,0 \%$ & $74,5 \%$ & $13,2 \%$ \\
\hline Virtual team & $62,1 \%$ & $1,9 \%$ & $36,9 \%$ & $1,9 \%$ \\
\hline Open-space & $61,5 \%$ & $5,4 \%$ & $31,7 \%$ & $7,2 \%$ \\
\hline Share-desks & $63,8 \%$ & $3,0 \%$ & $30,2 \%$ & $9,0 \%$ \\
\hline $\begin{array}{l}\text { Knowledge } \\
\text { management }\end{array}$ & $34,3 \%$ & $3,3 \%$ & $56,9 \%$ & $12,8 \%$ \\
\hline Telework & $59,8 \%$ & $11,2 \%$ & $24,9 \%$ & $12,9 \%$ \\
\hline NWOW & $\mathbf{4 3 , 0 \%}$ & $\mathbf{5 , 1 \%}$ & $\mathbf{4 5 , 9 \%}$ & $\mathbf{9 , 0 \%}$ \\
\hline
\end{tabular}

Source: Taskin and Ajzen, 2015

\section{Footnotes}

${ }^{1}$ Note that the acronym NWOW came first from Microsoft's product, https://news.microsoft.com/apac/2016/03/21/hack-your-way-to-the-new-world-of-work-hack5/\#sm.001ttf7hl1djkdbw11gb2wvwsuurc\#3hQU07u5MFbId2Cp.97

${ }^{1}$ This interview was leaded by Doug Gavel (Harvard University) on June 12, 2008. See Gavel, Doug. "Joseph Nye on Smart Power." Harvard Kennedy School Insight Interview, July 3, 2008.

\footnotetext{
' Note that the acronym NWOW came first from Microsoft's product, https://news.microsoft.com/apac/2016/03/21/hack-your-way-to-the-new-world-of-work-hack5/\#sm.001ttf7hl1djkdbw11gb2wvwsuurc\#3hQU07u5MFbld2Cp.97
} 